\author{
Violeta Todorović \\ Lazar Sedlarević ${ }^{\dagger}$ \\ Nenad Tomić ${ }^{\ddagger}$
}

JEL: G21, C32

DOI: 10.5937/industrija45-12571

UDC:

Original Scientific Paper

\title{
Impact of the single euro payment area on performance of banking sector
}

\author{
Article history: \\ Received: 30 November 2016 \\ Sent for revision: 12 December 2016 \\ Received in revised form: 7 March 2017 \\ Accepted: 17 March 2017 \\ Available online: 1 July 2017
}

\begin{abstract}
The European banking sector has gone through significant changes during the past decade. In addition to changes in the regulatory framework, it is important to emphasize establishment of a single payment area in the Euro-region (SEPA) whose primary objective was improvement of efficiency to all business entities. As the banks are one of the participants in the implementation process, the main objective of this study is to determine the effects of the implementation of SEPA rules on performance of banking sectors in the EMU. The paper presents a methodological framework and work on models to measure the impact of implementation SEPA rules on the performance of the banking sector. The model is based on regression in which SEPA payment instruments are used as independent variables. Data relates to banking sectors of 17 countries, members of EMU and cover the period 2002-2012. Each of the 17 members of the EMU is classified into one of the three groups, with as criteria of classification used indicator of the average participation of banking sector assets of a particular state in average assets of the banking sector EMU. Results of the research are in cohesion with the views that in the short term benefits of SEPA project is not enough in compare with the costs.
\end{abstract}

Keywords: SEPA, banking sector, performance, ROA, ROE.

\footnotetext{
* University of Kragujevac, Faculty of Economics

$\dagger$ University of Kragujevac, Faculty of Economics

$\ddagger$ University of Kragujevac, Faculty of Economics, ntomic@kg.ac.rs
} 
Todorović V. et al.:Impact of the single euro payment area on performance of banking..

\title{
Uticaj jedinstvene zone evro plaćanja na performanse bankarskog sektora
}

\begin{abstract}
Apstrakt: Bankarski sektor zemalja Evropske unije pretrpeo je značajne promene tokom protekle decenije. Pored promena regulatornog okvira, važno je istaći formiranje jedinstvene zone evro plaćanja (SEPA) čiji je primarni cilj unapređenje efikasnosti svih poslovnih entiteta. Pošto su banke učesnice u ovom procesu, cilj rada je da utvrdi efekat implementacije SEPA pravila na performanse bankarskog sektora Evropske monetarne unije. U radu je predstavljen metodološki okvir i postavljen model za merenje uticaja implementacije SEPA standarda na performanse bankarskog sektora. Model se zasniva na regresiji u kojoj se SEPA platni instrumenti koriste kao nezavisne promenljive. Podaci obuhvataju bankarske sektore 17 država članica EMU i odnose se na period 2002-2012. Svaka od 17 posmatranih država svrstana je u jednu od tri grupe, gde je kao indikator klasifikacije korišćeno učešće prosečne aktive bankarskog sektora posmatrane države u prosečnoj aktivi bankarskog sektora EMU.Rezultati istraživanja su u saglasju sa stavovima da su u kratkom roku koristi SEPA projektaniže od troškova.
\end{abstract}

Ključne reči: SEPA, bankarski sektor, performance banaka, ROA, ROE.

\section{Introduction}

Establishing of Single Euro Payment Area (SEPA) has its prehistory in the integration process of European continent. The period after the Second World War was characterized by the strengthening of the United States of America (USA) as a leader in the world, in political and economic sense. In order to stop USA dominance, key moment in Europe is Treaty of Rome, signed in 1957, which established the European Economic Community (EEC). From that moment, integration processes in Europe have two key characteristics: increasing the number of member states in the process of economic integration and the creation of stronger links between those countries. The final result of this process is the formation of the European Monetary Union (EMU) in 1999, with a single central bank - the European Central Bank (ECB).

During the whole process of economic integration and the establishment of $\mathrm{EMU}$, each member state has developed a national payment system, with specific requirements in terms of technology, standards, banking fees and types of services. With its establishment, the basic problem became the incompatibility of national systems. Mentioned incompatibility of payment systems leads to negative consequences for the banking sector in the European Union and the competitiveness of the European economy. The first attempt to eliminate the dangers was based on the equalization of tariffs on 
Todorović V. et al.:Impact of the single euro payment area on performance of banking..

payment services. However, a problem could not be solved in this way, since the national framework of payment systems (standards, technology, and even the regulations) remain unchanged. The implementation process is complex and requires adequate regulatory basis in the form of documents of relevant institutions. Banks and other institutions, the holders of the payment system, in this process must adapt to the new standards, implementing new technology. These requirements can produce significant cost pressure in the initial stages of an implementation process.

Considering the above, the subject of research will be the process of implementing SEPA rules on the territory of the European Monetary Union. The aim of the research is to determine whether the development and implementation of the SEPA rules affect the performance of the banking sector in the EMU. In addition, it is necessary to determine the nature of the impact on these elements. The key hypothesis is: The development and implementation of a single payment area lead to the deterioration of the performance of banking sector in the EMU. In addition to this, we utilized the auxiliary hypotheses which are detailed in the paper.

The paper is structured in five parts. After the introductory part, the second part explains the concept of a single payment area in the Euro-region, where are defined motives of formation, structure and regulation of the system and the expected effects of the implementation process. The third section presents a methodological framework and work on models to measure the impact of implementation SEPA rules on the performance of the banking sector. Also in this section are presented methods of statistical data processing. In the fourth part, we point to the results obtained in the research. At the end of this paper, there are given the conclusions of the research on which it is given a final judgment on the validity of the hypotheses.

\section{Single Euro Payment Area}

Previous research in this area in most cases is a theoretical analysis of the potential effects of the of implementation SEPA rules in the Euro area. In addition, research is primarily based on the analysis of payment systems, thereby ignoring the effects of of implementation SEPA rules on the performance of banks and the banking sector. Martikainen et al. (2013) suggest that it is still too early to explore the effects of the of implementation SEPA rules, due to differences in the period of its implementation between the countries of the European Union (EU) and the European Monetary Union (EMU). However, as the integral part of the development process of SEPA scheme, banks are required cost adjustments in the initial implementation 
Todorović V. et al.:Impact of the single euro payment area on performance of banking..

phases, it is reasonable that the effects on their performance can now be measured.

The idea of formation a single payment area in the Euro-region is relatively new and represents a significant innovation for all participants in the financial system. Actually, SEPA can be considered as an initiative to create an integrated European payments area in which all payments are subject to uniform standards, terms and conditions. SEPA area in the Euro-region now includes 33 countries, all EU member states and Switzerland, Iceland, Liechtenstein, Norway and Monaco.

\subsection{Motives, system and regulation of SEPA project}

Keeping in mind the history of the integration processes on the territory of Europe as the main reason for formation of a single payment area it could be pointed out insufficient degree in integration of payment systems of member states of the European Monetary Union (EMU). With the development of EMU and later banking union (Šoškić, 2015), the existence of only national payment systems caused lack of competitiveness of European economy and impedes the operations of companies. Equalization of tariffs on payment services (for all credit transfers value to $12,500 €$ ) was aimed at eliminating these problems (EC 2001). However, the existence of different payment instruments and standards, as well as the necessity of multiple accounts contributed to the creation of cost pressure on the participants of the payment system.

Kokkola (2010) points out that in terms of the structure of SEPA significantly differ from the national payment system. SEPA system is organized in three levels, where the first level is related to the infrastructure of the system, the second level is a specific SEPA schemes, and the third level consists of specific products and services developed by the banks and payment institutions. How infrastructure and schemes are separated, providers can compete with each other and thus contribute to the achievement of the efficiency of the system.

However, only adequate infrastructure is not sufficient for successful operation of the system. Therefore, the important place occupied by the attempts of the European Commission (EC 2007; EC 2009; EC 2012) that the behavior of SEPA system is reduced to "the right measure". Directive of the European Commission in 2007th primarily regulate the relationship between SEPA providers (banks and payment institutions) and their customers. Due to underdeveloped infrastructure of systems, and the existence of major differences between the levels of development in certain countries, this directive contribution was determination of responsibility in case of default of payment, or unauthorized execution of payments. However, regulation of the 
Todorović V. et al.:Impact of the single euro payment area on performance of banking..

environment and instruments request from banks and providers to customize services, as in the following phases can have negative effects (Wandhöfer, 2008). The next regulatory step meant the equalization of tariffs on national and cross-border payment instruments a single bank. However, this meant that banks cannot charge higher fees on activities that potentially carry more risks, which represented a significant impact on their business. The last document (EC 2012) places an emphasis on the deadline for the transition from national to SEPA payment schemes. In this domain, a distinction is made between the EMU countries and non-member countries (EMU members are required to replace the national scheme of credit transfer and direct debit with SEPA compatible by February 1st of 2014, while the deadline for other countries October 31, 2016). In addition, the paper contributes to the (EBA 2012): improving communication between participants, using the ISO 20022 standards, improving the technical interoperability of payment systems, increase the security of the system and its users by introducing additional measures.

Developed SEPA rules apply to the whole infrastructure system. However, it is possible to distinguish between rules that are common for all parts of the system and the rules developed for its individual elements. Thus it is possible to single out specific rules relating on three payment instruments, as follows:

1. SEPA credit transfers;

2. SEPA direct debit and

3. SEPA credit cards.

Credit transfer allows customers to make payments in amounts that exceed the available funds, whereby the payer initiates the payment by issuing an order for the transfer of funds to the bank or service provider. By using SEPA rules in the field of credit transfers, it is created a tool that let users bring certain benefits, particularly in terms of functional and cost. Thus Vuksanović et al. (2011) as the basic characteristics of SEPA credit transfers pointed: the broad approach, debit, which refers to the total amount of the bill, the absence of limits to the amount of payment; separation rules of the payment system infrastructure and payment technology, the ease of identifying accounts with International Bank Account Number (IBAN) and Bank Identification Code $(B I C)$ and the ranking procedures in case of rejection or return orders. In the process of initiating and calculating it is significant application of the concept of Straight through Processing (STP) due to a higher degree of penetration of the system, especially due to the high cost of the difference between STP and non-STP system becomes larger (Danese 2008).

Unlike credit transfer, direct debit enable approval and posting of transfer of funds from the buyer to the seller's account under the actual funds available. SEPA direct debit scheme is presented 2009, revised the 2012 (EPC 2012a; EPC 2012b) and it could be distinguished two models: the basic SEPA direct 
Todorović V. et al.:Impact of the single euro payment area on performance of banking..

debit scheme (SDD Core) and SEPA direct debit scheme appropriate for transactions between businesses (B2B SDD). Both models use the same procedures, but there are differences in certain characteristics attributed to the specific nature of transactions between companies. Therefore, it can be noted that the B2B SDD scheme in terms of the general characteristics of the amended version of the core SDD scheme. As the difference between the above mentioned scheme can be pointed out the necessity of granting individual assignments, while the main SDD scheme does not have this feature. However, Tabasso and Buschman (2008) pointed out the risk of lack of acceptance of the SDD scheme, which may make question about the final results of the entire project for banking institutions and corporations.

Unlike credit transfers and direct debits, credit cards have not been primary subject of SEPA initiative. However, the existence of large differences, both between national payment system and in terms of price, led to the difficulty of integrating systems across the Eurozone. The above mentioned problems, as pointed out Chaplin (2008) had a negative effect on the efficiency and the growth of the payment systems. Although credit cards have become part of the SEPA initiative, there is an evident difference in treatment in relation to credit transfer and direct debit. In the area of credit cards is not developed unique SEPA schemes already established SEPA Card Framework (SCF) relevant for the specific scheme developed by banks and payment institutions (EPC 2009). Scheme compatible with SCF have the following characteristics: they are used on entire area of the Euro zone; service prices are transparent, functioning payment system is independent from issue of the card, EMV chip technology and the existence of a SEPA license.

Uniform standards, which apply to all cards has contribution in achieving operational efficiency, but also increase the safety of their use. EMV chip technology defines minimum standards in terms of equipment terminals and the credit cards and in view of execution of the transactions with payment cards.

\subsection{The expected effects of the of implementation of SEPA system}

Lack of competitiveness of the European economy, hampered operations of business entities, as well as the need of owning multiple accounts to carry out transactions abroad were the major limiting factors to achieve efficiency and growth. The formation of EMU did not contribute to greater integration of financial markets and payment systems, because of significant differences in technical characteristics and operational procedures of the national payment system. Even creation of TARGET system, due to the limited harmonization on level of functioning of monetary policy did not lead to the harmonization of the national payment systems. The answer to these problems was formation 
Todorović V. et al.:Impact of the single euro payment area on performance of banking..

of a single payment area, which would operate as a factor of harmonization and linking different national payment systems.

The formation of the European Payments Council in 2002 was aimed at the establishment of an efficient payment system that would eliminate the deficiencies identified. Although the institutional elements of the SEPA project was presented a few years later, the changes in the banking industry and payment systems have started immediately, primarily because the need for large adjustments. Balanced distribution in implementation of the SEPA rules did not exist, and it is possible to single out four possible scenarios (Schmiedel 2007):

1. The basic scenario;

2. Coexistence of payment schemes;

3. Ideal SEPA system;

4. E-SEPA.

The basic scenario is based on the assumption that in the future SEPA payment schemes and rules will not be incorporated into the payment system. The second scenario assumes that national and SEPA schemes co-exist, which means that banks beside traditional instruments have to offer SEPAcompatible instruments. In the short term this leads to an increase in costs due to the creation of new schemes and their parallel use with existing schemes. However, revenue in the short term cannot reach the desired level, and the final result of coexisting schemes on the performance of banks is negative. This view is represented by Bott (2009), who points out that the high cost of establishing SEPA instruments and the high cost of closing national scheme cannot provide benefits for all participants in the system. Ideal SEPA system, which have been used all the advantages of a single payments area is the third scenario. This scenario involves the completion of the transition from national to SEPA payment schemes compatible and therefore all transactions must be executed by SEPA compatible instruments. In such an environment it is possible to achieve benefits for all participants. The last scenario, e-SEPA, shows a system that works by using electronic channels, mechanisms and processes. In such environment, significant cost savings are achievable in the long run, given that in the short paradox arises because of the profitability of investment in information technology (Beccalli 2007).

These scenarios can be seen as an implementation phases of the process SEPA rules. The initial phase of of implementation corresponds to the baseline scenario, where SEPA instruments are not functioning because of the cost and operational unattractiveness. The second phase can be described by scenario of coexistence scheme payments until SEPAcompatible instruments do not become an attractive and cost effective which will allow transition to the next phase of an implementation process. In the third phase, described by ideal scenario SEPA system, SEPA instruments 
Todorović V. et al.:Impact of the single euro payment area on performance of banking..

become dominant and the expected benefits should be fully utilized. The introduction of information technologies in the SEPA process (e-SEPA) characterizes the last phase of implementation. Based on current progress in the implementation process, it can be concluded that the entire project is in the second phase, where preparations for the transition to the third stage is almost complete. The justification of this view is in the coexistence of national and SEPA schemes, with the SEPA schemes become attractive to users.

The new system has a variety of effects that can be felt by certain interest groups. ECB (2009) as the two main stakeholders separates: SEPA service providers (banks, credit institutions and card industry) and SEPA service users (merchants and corporations, customers, banks and payment institutions, small businesses and public institutions). Determining the actual impact is further compounded by the fact that some participants may occur as providers and customers SEPA services. Bolt and Humphrey (2007) point out that, due to the integration of national markets, cross-border transactions can be executed as easily as transactions at the national level. In addition to the ease of conducting transactions, the authors point to the achievement of economies of scale and cost savings that are possible in terms of disintegrated system.

While banks are primarily credit-deposit institutions significant segment of their business is the mediation of payment service, since $15-30 \%$ of revenues, $30-40 \%$ of expenditures and $10-25 \%$ of profit are created in these transactions (De Ploey et al. 2005; Skinner 2008; De Schrevel 2008). Factors such as market integration, the new payment system infrastructure and increase mobility, make banks more exposed to competition from other banks and payment institutions. All this with significant costs of developing new instruments have effects on the cost side and leads to their increase. In the long run, expectations are focused on reducing costs so that the final effect on the performance of banks is positive. However, the distribution of benefits between banks is not uniform (Kemppainen 2008). In his study, the author points out that the banks which are facing with international competition will earlier realize benefits than the banks in national environment.

The major feature of the company during the SEPA environment distinguishes the achievement of cost-effectiveness. Adoption of uniform processes and payment mechanisms, companies are able to more effectively use available resources. In this new environment, companies integrate different accounts into a single, for all inflows and outflows. Therefore, it is possible to achieve savings in cost and time necessary to complete a transaction. However, the final effects of the corporation in a large extent depend on the relationship between banks - corporation (Ryan 2008). Banks may cause the integration process required to implement the respective requirements in terms of technical and organizational standards, which may affect the final effects are 
Todorović V. et al.:Impact of the single euro payment area on performance of banking..

less desirable. The special significance in the SEPA environment get services based on the STP concept, such as electronic invoicing (e - invoicing) and electronic reconciliation (e - reconciliation).

Majority of service industries are now focusing on customer needs. If the client is in the center of the payment system, they can feel the benefits which are primarily reflected in higher service quality and their lower prices. In a study of clients position in payment systems (Leinonen 2008), the author points out that the development of the payment system has not reached the desired level when are concerned customer needs because of inadequate market structure, lack of regulation and lack of transparency of prices and services. However, customers can expect cost savings due to the possibility of using a single bank account throughout the SEPA area.

\section{Research methodology}

\subsection{Survey description}

The data about the performance the banking sector, which were used in this study, were obtained from the official database of the European Central Bank. Data relates to banking sectors of 17 countries, members of EMU and cover the period 2002-2012. Also, quantitative indicators on the use of SEPA instruments are taken from the Internet address (www.ecb.europa.eu/paym/sepa/about/indicators/html/index.en.html).

Due to the more precise interpretation of the results and drawing conclusions, each of the 17 members of the EMU is classified into one of the three groups, with as criteria of classification used indicator of the average participation of banking sector assets of a particular state in average assets of the banking sector EMU. Based on the above criterion, the following groups are created:

1. Group A - Participation less than 1\% (Estonia, Cyprus, Malta, Slovenia and Slovakia);

2. Group B - Participation between 1 and $5 \%$ (Austria, Belgium, Greece, Ireland, Luxembourg, Portugal and Finland);

3. Group C - Participation greater than 5\% (Italy, Germany, France, the Netherlands and Spain).

For each group was calculated benchmark, obtained as the average of the observed indicators for a specific group of countries. For example, the value of the rate of return on total assets (return on assets - ROA) for the group of countries $\mathrm{C}$ was calculated as the average value of ROA for the banking sectors of the countries classified in group C. 
Todorović V. et al.:Impact of the single euro payment area on performance of banking..

All countries classified in group A have become full members of the EU in 2004th. Estonia, Slovenia and Slovakia, as well as the former socialist countries, have been able to quickly implement the necessary reforms which made them closer to Western Europe. Nevertheless, at the time of their accession to the EU there are some differences between the candidate countries and the EU countries, which reason is the existence of similar patterns in the transition process in these countries.

Figure 1.ROE of observed group of countries in the period 2002-2012.

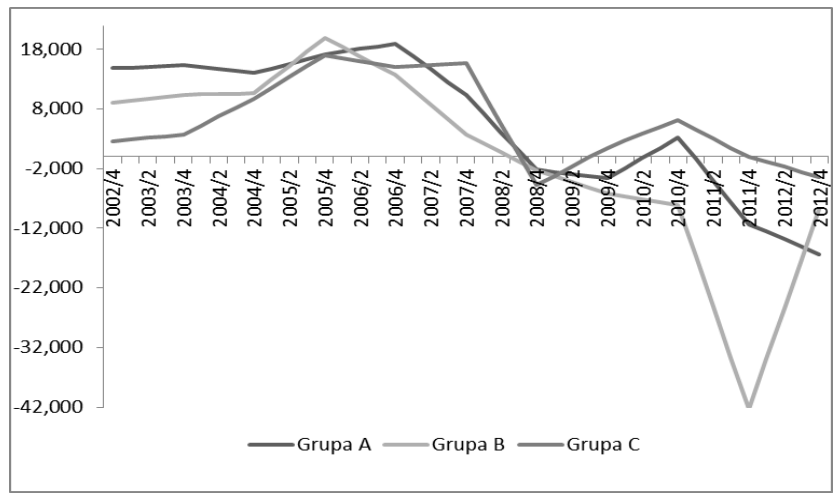

Source: Authors calculations

Fig. 1 shows the actual rate of return on equity (ROE) the observed groups of countries. In terms of ROE trends can be identified the following trends: a) the beginning of the period was characterized by diversity in the rates of ROE between the groups, b) the period of 2004-2010th differences in the ROE were not significant, and c) after the 2010th differences in height ROE mentioned group of countries are becoming significant.

\subsection{SEPA-compatible instruments - efficiency measures of the implementation process}

There are plenty of researches measuring the impact of asset quality on bank profitability (for example - Kasavica, Jović, 2015). However, in the relevant literatures it is not developed a model designed to determine the effects of of implementation SEPA rules on the performance of the banking sector. Therefore, it is required to display the model used in this study. The model is based on the aforementioned SEPA payment instruments, SEPA credit transfers and SEPA direct debit and SEPA credit cards, as shown in formula (1): 
Todorović V. et al.:Impact of the single euro payment area on performance of banking..

$$
Y_{i}=\beta_{o}+\Sigma \beta_{i j} X_{j}+\varepsilon_{i}
$$

Where:

Yi - dependent (endogenous) variable;

$\mathrm{Xi}$ - independent (exogenous variable) and

$\mathrm{Ei}$ - no identified random variable (error).

Independent variables in the model are:

a) $X_{1}$ - Average share of SEPA compliant credit transfers and direct debits in total transactions of credit transfers and direct debits SCT+SDD;

b) $\mathrm{X}_{2}$ - Participation of transaction made through cards that meet the EMV standard in the total transactions executed by credit cards EMV.

Although these three elements instruments of the SEPA systems together indicate the degree of of implementation SEPA rules, it is necessary to point out modifications to the model used. Fig. 2 shows the movements SEPA compliant instruments on the level EMU during the period. A value of zero indicates that at the time SEPA schemes have not been developed. However, these values should be taken into consideration since the development of SEPA schemes required certain adjustments, even when they have not been in use. Also, bearing in mind that the rules of SEPA credit transfers and direct debits developed in parallel, and that the individual members of the EMU decided to replace the national SDD schemes with SCT schemes, the progress in the implementation of these schemes is presented one indicator (SCT+SDD).

Figure 2. Average value of SEPA compliant instrument on the EMU level during the period 2002-2012

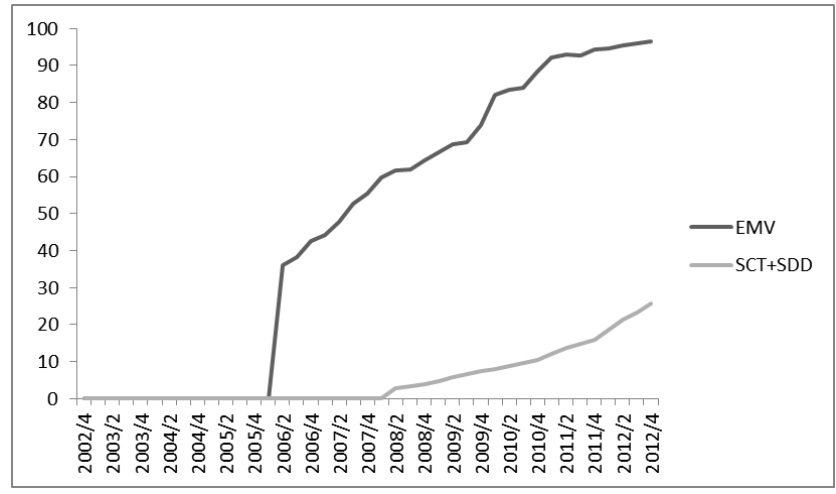

Source: Authors calculations

Industrija, Vol.45, No.2, 2017 
Todorović V. et al.:Impact of the single euro payment area on performance of banking..

At EMU level, there is a significant difference in the efficiency of implementation process between the payment cards, on the one hand, and credit transfers and direct debits on the other hand. EMV technology equipped payment cards represents almost $100 \%$ of all payment cards used in the transactions in the area of EMU. On the other hand, the percentage of the credit transfers and direct debits schemes compatible SEPA and the by far lower. These indicators will allow the detection of effects of of implementation SEPA rules on the performance of the banking sector in the EMU.

The presented model also has some limitations. First, this model shows the effects of individual payment instruments on performance of the banking sector. In practice, these instruments may have a synergic effect, where through cross-selling could bring additional revenues. Second, the model does not take into consideration the existence of other payment institutions which could provide SEPA services, but it is based on the assumption that only banks can provide SEPA compatible services. The third limitation of the model refers to its temporal validity. More precisely, the model is applicable in conditions where national and SEPA schemes coexist, but not when SEPA schemes become dominant. However, despite these limitations, the model is adequate for measuring the effects of implementation SEPA rules on the performance of the banking sector.

\subsection{Research objectives and hypotheses}

The main goal of this research is to determine whether the development and implementation of the SEPA rules affect the performance of the banking sector in the EMU, and if they have to determine their nature. Based on the fact that today implementation process in the second phase, the phase coexistence of national and SEPA payment schemes, the basic hypothesis is: The development and implementation of a single payment area lead to the deterioration of the performance of banking sector in the EMU. Based on this, we can distinguish the following hypotheses which will be used to determine the nature of the effects of the implementation. These are:

The hypothesis relating to ROA:

$\mathrm{H}_{1}$ : The banking sectors of the countries with a higher share of SCT + SDD have lower ROA.

$\mathrm{H}_{2}$ : The banking sectors of the countries with a higher share of EMV have lower ROA.

The hypothesis related to ROE:

$\mathrm{H}_{3}$ : The banking sectors of the countries with a higher share of SCT + SDD have a lower ROE. 
Todorović V. et al.:Impact of the single euro payment area on performance of banking..

$\mathrm{H}_{4}$ : The banking sectors of the countries with a higher share of EMV have a lower ROE.

These hypotheses will be checked for each of the three groups of countries. As the dependent variable will be observed ROA and ROE, while the independent variables will be already mentioned SCT + SDD and EMC. Therefore, we can speak about two models, where the first dependent variable ROA, while in the second dependent variable is ROE. The collected data will be analyzed using a variety of statistical methods, in order to determine their nature and existence of correlation. At the end, over collected data will be conducted the action of multiple linear regression using the statistical software SPSS 20.

\section{Empirical results}

\subsection{Descriptive statistics}

Table 1 presents the descriptive statistics of the research.

Table 1. Descriptive statistics

\begin{tabular}{|l|c|c|c|c|}
\hline & Minimum & Maximum & Mean & Std. Deviation \\
\hline & \multicolumn{5}{|c|}{ Grupa A } \\
\hline EMV &, 00 & 98,96 & 41,9772 & 39,17821 \\
\hline ROE & $-16,31$ & 18,96 & 5,9550 & 10,98336 \\
\hline ROA &,- 24 & 1,68 &, 7506 &, 71857 \\
\hline SCT+SDD &, 00 & 30,42 & 6,4767 & 8,91991 \\
\hline & \multicolumn{5}{|c|}{ Grupa B } \\
\hline EMV &, 00 & 96,91 & 53,9307 & 40,53160 \\
\hline ROE & $-42,24$ & 19,96 &,- 0268 & 15,54480 \\
\hline ROA & $-1,38$ &, 88 &, 1323 &, 62536 \\
\hline SCT+SDD &, 00 & 36,09 & 7,3886 & 10,35300 \\
\hline \multicolumn{5}{|c|}{ Grupa C } \\
\hline EMV &, 00 & 93,21 & 43,0544 & 35,73597 \\
\hline ROE & $-4,74$ & 17,01 & 6,1924 & 6,72094 \\
\hline ROA &,- 22 &, 96 &, 3998 &, 38781 \\
\hline SCT+SDD &, 00 & 10,07 & 1,8447 & 3,15117 \\
\hline
\end{tabular}

There are some existing differences between these groups of countries. In terms of share of transactions made with payment cards that meet the EMV standard in the total transactions executed by payment cards, there is no significant difference. All three groups have nearly equal values of the observed variables (EMV), but the countries in Group B in the average stand out as advanced. The movement variables SCT + SDD, there are some differences between the groups. The highest values can be observed within 
Todorović V. et al.:Impact of the single euro payment area on performance of banking..

the B group of countries, while the countries classified in group C are characterized by the lowest values of SEPA compliant credit transfers and direct debits.

During the period, all three groups have been, on average, achieved a low rate of return on assets compared with conventional rates of $1 \%$. In this, particular emphasis is on countries in group B (an average ROA $0.1323 \%$ ). In terms of ROE trends between groups it can be observed more significant differences, with the worst results in group $B$, and the best in group A. For all three groups of countries, it is characteristic that during the period recorded a negative rate of return on assets and equity, with the worst result achieved country from the group B.

\subsection{Correlation analysis}

In order to determine the existence of correlation between the observed variables, it is necessary to determine the nature of the data. Therefore, it is conducted the Kolmogorov-Smirnov test of normality tests, whose results are shown in Table 2.

Table 2. Test of normal distribution of data

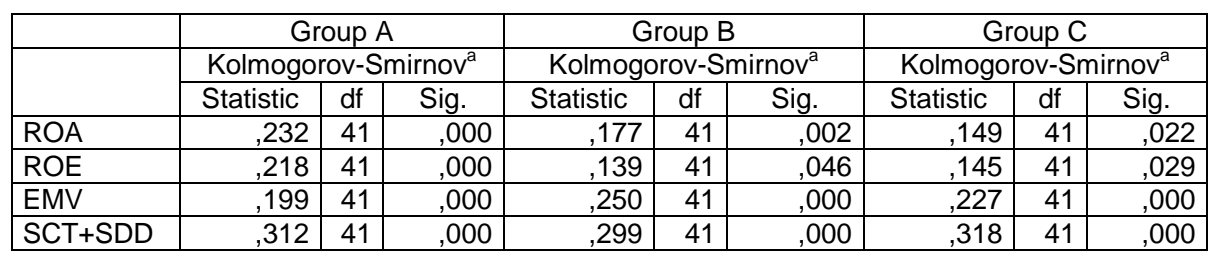

a. Lilliefors Significance Correction

The values of the Kolmogorov-Smirnov test of normality, indicates that none of the observed variables don't have the normal distribution (statistical significance is less than 0,200 ). Therefore, further analysis requires the use of non-parametric tests. Thus, for determining the correlation should be applied Spearman's correlation analysis.

Table 3 presents the results of correlation analysis. Correlations between variables indicate that there is a statistically significant correlation in each of the three groups of countries, but the intensity of this relationship the largest in the group B. Within each group, ROA is in correlation with the EMV and SCT + SDD, but the intensity of it is weakest in third group of countries. In addition, between ROE and independent variables, there was a statistically significant correlation, that excels in the group $B$ countries. For example, the highest correlation coefficient is between ROA (the dependent variable) and SCT+SDD in group B (Spearman's coefficient of 0.910 ). In order to determine 
Todorović V. et al.:Impact of the single euro payment area on performance of banking..

the nature of the relationship between the dependent and independent variables, the following section will present the results of multiple regression analysis.

Table 3. Correlation analysis

\begin{tabular}{|c|c|c|c|}
\hline & & EMV & $\mathrm{SCT}+\mathrm{SDD}$ \\
\hline \multicolumn{4}{|c|}{ Group A } \\
\hline \multirow{2}{*}{$\mathrm{ROA}$} & Correlation Coefficient &,$- 859^{*}$ &,$- 890^{* *}$ \\
\hline & Sig. (2-tailed) &, 000 &, 000 \\
\hline \multirow{2}{*}{ ROE } & Correlation Coefficient &,- 786 &,- 799 \\
\hline & Sig. (2-tailed) &, 000 &, 000 \\
\hline \multicolumn{4}{|c|}{ Group B } \\
\hline \multirow{2}{*}{$\mathrm{ROA}$} & Correlation Coefficient &,- 907 &,- 910 \\
\hline & Sig. (2-tailed) &, 000 & ,000 \\
\hline \multirow{2}{*}{ ROE } & Correlation Coefficient &,$- 900^{*}$ &,$- 905^{* *}$ \\
\hline & Sig. (2-tailed) &, 000 &, 000 \\
\hline \multicolumn{4}{|c|}{ Group C } \\
\hline \multirow{2}{*}{ ROA } & Correlation Coefficient &,- 595 &,- 723 \\
\hline & Sig. (2-tailed) &, 000 &, 000 \\
\hline \multirow{2}{*}{ ROE } & Correlation Coefficient &,- 759 &,- 842 \\
\hline & Sig. (2-tailed) &, 000 & ,000 \\
\hline
\end{tabular}

\subsection{Multiple-regression analysis}

Model of regression analysis used in this study as the dependent variables have ROA and ROE, while the independent variables are SCT + SDD and EMC. Previously presented model will be tested in each of the three groups of countries.

Within group A, first is used as a dependent variable rate of return on assets $(\mathrm{ROA})$. The results shown in Table 4 indicate that $77.5 \%$ changes of variables ROA describes EMV + SDD and SCT $\left(R^{2}=0.775\right)$.

Table 4. Regression model - group A (ROA as dependent variable)

\begin{tabular}{|l|c|c|c|c|}
\hline Model & $\mathrm{R}$ & $\mathrm{R}$ Square & Adjusted R Square & Std. Error of the Estimate \\
\hline 1 &, $880^{\mathrm{a}}$ &, 775 &, 763 &, 34970 \\
\hline
\end{tabular}

a. Predictors: (Constant), EMV, SCT+SDD

b. Dependent Variable: $R O A$

Based on the information in Table 5, it can be concluded that the variable EMV has a statistically significant impact on ROA. On the other hand, the impact of variables on SCT + SDD ROA is not statistically significant. For 
Todorović V. et al.:Impact of the single euro payment area on performance of banking..

checking multicolinearity we used variance inflation factor (VIF). As O'Brien (2007) points out in order to model relevance VIF value must be less than 10.

Table 5. Coefficients for regression - group A (ROA as dependent variable)

\begin{tabular}{|c|c|c|c|c|c|c|c|c|}
\hline & \multirow[t]{2}{*}{ Model } & \multicolumn{2}{|c|}{$\begin{array}{l}\text { Unstandardized } \\
\text { Coefficients }\end{array}$} & \multirow{2}{*}{$\begin{array}{c}\begin{array}{c}\text { Standardize } \\
\mathrm{d} \\
\text { Coefficients }\end{array} \\
\text { Beta }\end{array}$} & \multirow[t]{2}{*}{$\mathrm{t}$} & \multirow[t]{2}{*}{ Sig. } & \multicolumn{2}{|c|}{$\begin{array}{l}\text { Collinearity } \\
\text { Statistics }\end{array}$} \\
\hline & & B & $\begin{array}{l}\text { Std. } \\
\text { Error }\end{array}$ & & & & $\begin{array}{c}\text { Tolera } \\
\text { nce }\end{array}$ & VIF \\
\hline \multirow{3}{*}{1} & (Constant) & 1,450 &, 085 & & 16,966 & ,000 & & \\
\hline & SCT+SDD & ,011 & ,014 & ,141 & ,821 & , 417 & ,201 & 4,966 \\
\hline & EMV &,- 018 & ,003 & $-1,004$ & $-5,855$ & ,000 & 201 & 4,966 \\
\hline
\end{tabular}

a. Dependent Variable: $R O A$

When observe ROE as a dependent variable the data in Table 6 shows that $88.2 \%$ of the variability is explained by the variables EMV and SCT+SDD.

Table 6. Regression model - group A (ROE as dependent variable)

\begin{tabular}{|c|c|c|c|c|}
\hline Model & $\mathrm{R}$ & $\mathrm{R}$ Square & Adjusted R Square & Std. Error of the Estimate \\
\hline 1 &, $939^{\mathrm{a}}$ &, 882 &, 876 & 3,87019 \\
\hline
\end{tabular}

a. Predictors: (Constant), EMV, SCT+SDD

b. Dependent Variable: $R O E$

Table 7 presents the data on the coefficients in the regression model, indicating that the variables SCT + SDD and EMC have a statistically significant impact on ROE during the period.

Table 7. Coefficients for regression - group A (ROE as dependent variable)

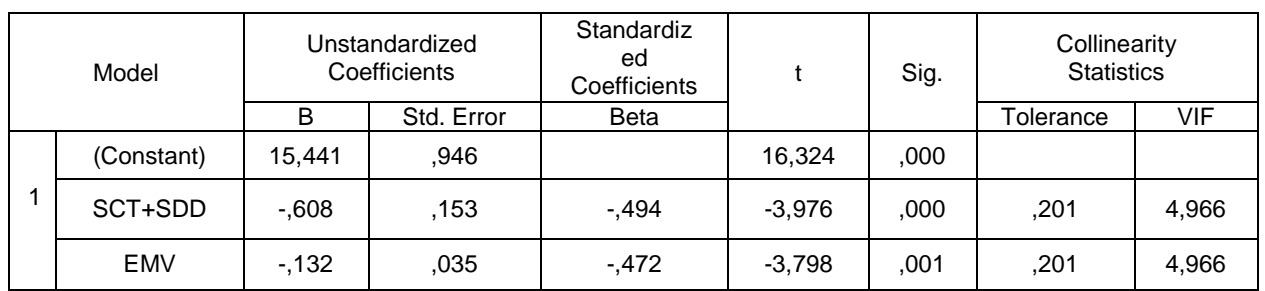

a. Dependent Variable: ROE

The testing results of the second group are shown in Tables 8, 9, 10 and 11. In the first place, as the dependent variable was observed rate of return on assets (ROA). Model shows that $79.5 \%$ of ROA changes in banking sector in the countries from second group, is explained by changes in the SCT+SDD and EMV. 
Todorović V. et al.:Impact of the single euro payment area on performance of banking..

Table 8. Regression model - group B (ROA as dependent variable)

\begin{tabular}{|c|c|c|c|c|}
\hline Model & $\mathrm{R}$ & $\mathrm{R}$ Square & Adjusted R Square & Std. Error of the Estimate \\
\hline 1 &, $892^{\mathrm{a}}$ &, 795 &, 784 &, 29059 \\
\hline
\end{tabular}

a. Predictors: (Constant), EMV, SCT $+S D D$

b. Dependent Variable: ROA

In the second group of countries, both independent variables have a statistically significant impact on ROA. In addition, the VIF value indicates that the model has no problem with multicollinearity.

Table 9. Coefficients for regression - group $B$ (ROA as dependent variable)

\begin{tabular}{|c|c|c|c|c|c|c|c|c|}
\hline & \multirow{2}{*}{ Model } & \multicolumn{2}{|c|}{$\begin{array}{l}\text { Unstandardized } \\
\text { Coefficients }\end{array}$} & \multirow{2}{*}{$\begin{array}{c}\begin{array}{c}\text { Standardize } \\
\mathrm{d} \\
\text { Coefficients }\end{array} \\
\text { Beta }\end{array}$} & \multirow{2}{*}{$t$} & \multirow{2}{*}{ Sig. } & \multicolumn{2}{|c|}{$\begin{array}{l}\text { Collinearity } \\
\text { Statistics }\end{array}$} \\
\hline & & B & $\begin{array}{l}\text { Std. } \\
\text { Error }\end{array}$ & & & & $\begin{array}{c}\text { Toleran } \\
\text { ce }\end{array}$ & VIF \\
\hline \multirow{3}{*}{1} & (Constant) & 689 & ,077 & & 8,929 & , 000 & & \\
\hline & $\mathrm{SCT}+\mathrm{SDD}$ &,- 038 &, 006 &,- 634 & $-6,290$ &, 000 &, 532 & 1,880 \\
\hline & EMV &,- 005 &, 002 &,- 329 & $-3,264$ &, 002 &, 532 & 1,880 \\
\hline
\end{tabular}

a. Dependent Variable: $R O A$

Changes in the ROE movement in the second group of countries can be explained by the $76.5 \%$ of the variability of SCT and SDD + EMV. The values of the regression coefficients in Table 11 and $p$ values indicate that the independent variables have a statistically significant impact on the changes of $\mathrm{ROE}$ in the period.

Table 10. Regression model - group B (ROE as dependent variable)

\begin{tabular}{|c|c|c|c|c|}
\hline Model & $\mathrm{R}$ & $\mathrm{R}$ Square & Adjusted R Square & Std. Error of the Estimate \\
\hline 1 &, $874^{\mathrm{a}}$ &, 765 &, 752 & 7,73952 \\
\hline
\end{tabular}

a. Predictors: (Constant), EMV, SCT+SDD

b. Dependent Variable: $R O E$

Table 11. Coefficients for regression - group B (ROE as dependent variable)

\begin{tabular}{|c|c|c|c|c|c|c|c|c|}
\hline & \multirow{2}{*}{ Model } & \multicolumn{2}{|c|}{$\begin{array}{l}\text { Unstandardized } \\
\text { Coefficients }\end{array}$} & \multirow{2}{*}{$\begin{array}{c}\begin{array}{c}\text { Standardize } \\
\mathrm{d} \\
\text { Coefficients }\end{array} \\
\text { Beta }\end{array}$} & \multirow{2}{*}{$t$} & \multirow{2}{*}{ Sig. } & \multicolumn{2}{|c|}{$\begin{array}{l}\text { Collinearity } \\
\text { Statistics }\end{array}$} \\
\hline & & B & $\begin{array}{l}\text { Std. } \\
\text { Error }\end{array}$ & & & & $\begin{array}{c}\text { Toleran } \\
\text { ce }\end{array}$ & VIF \\
\hline \multirow{3}{*}{1} & (Constant) & 13,359 & 2,055 & & 6,502 & ,000 & & \\
\hline & $\mathrm{SCT}+\mathrm{SDD}$ &,- 955 & ,162 &,- 636 & 5,892 & ,000 & ,532 & 1,880 \\
\hline & EMV &,- 117 & ,041 &,- 306 & 2,835 & ,007 & ,532 & 1,880 \\
\hline
\end{tabular}

a. Dependent Variable: ROE 
Todorović V. et al.:Impact of the single euro payment area on performance of banking..

The collected data about third group of countries have been tested in the presented models. The data in Tables 12 and 13 indicates that the independent variables explain $59.1 \%$ of the variability of ROA in the period. Analysis of the impact of implementation SEPA payment instruments on ROA of banking sector (Table 13) in the within group 3 indicates that EMV has a statistically significant impact on ROA, while SCT + SDD does not.

Table 12. Regression model - group C (ROA as dependent variable)

\begin{tabular}{|c|c|c|c|c|}
\hline Model & $\mathrm{R}$ & $\mathrm{R}$ Square & Adjusted R Square & Std. Error of the Estimate \\
\hline 1 &, $769^{\mathrm{a}}$ &, 591 &, 569 &, 25457 \\
\hline
\end{tabular}

a. Predictors: (Constant), EMV, SCT+SDD

b. Dependent Variable: $R O A$

Table 13. Coefficients for regression - group C (ROA as dependent variable)

\begin{tabular}{|c|c|c|c|c|c|c|c|c|}
\hline & \multirow{2}{*}{ Model } & \multicolumn{2}{|c|}{$\begin{array}{l}\text { Unstandardized } \\
\text { Coefficients }\end{array}$} & \multirow{2}{*}{$\begin{array}{c}\begin{array}{c}\text { Standardized } \\
\text { Coefficients }\end{array} \\
\text { Beta }\end{array}$} & \multirow{2}{*}{$\mathrm{t}$} & \multirow{2}{*}{ Sig. } & \multicolumn{2}{|c|}{$\begin{array}{l}\text { Collinearity } \\
\text { Statistics }\end{array}$} \\
\hline & & B & $\begin{array}{l}\text { Std. } \\
\text { Error }\end{array}$ & & & & $\begin{array}{c}\text { Toleran } \\
\text { ce }\end{array}$ & VIF \\
\hline \multirow{3}{*}{1} & (Constant) & ,708 & ,066 & & 10,796 & , 000 & & \\
\hline & $S C T+S D D$ &,- 038 & ,019 &,- 307 & $-1,958$ & 058 & 438 & 2,281 \\
\hline & EMV &,- 006 & ,002 &,- 511 & $-3,261$ & ,002 & 438 & 2,281 \\
\hline
\end{tabular}

a. Dependent Variable: ROA

The data in table 14 show the effect of independent variables on the ROE at the level of group $C$ in the period. Model indicates that independent variables (SCT+SDD and EMV) can explain $32.9 \%$ of changes in ROE in the period, which is significantly lower than in the other groups. Based on the regression coefficients, shown in Table 15, we can conclude that none of the independent variables has significant effect on ROE at the level of group $C$

Table 14. Regression model - group C (ROE as dependent variable)

\begin{tabular}{|c|c|c|c|c|}
\hline Model & $\mathrm{R}$ & $\mathrm{R}$ Square & Adjusted R Square & Std. Error of the Estimate \\
\hline 1 &, $574^{\mathrm{a}}$ &, 329 &, 294 & 5,64660 \\
\hline
\end{tabular}

a. Predictors: (Constant), EMV, SCT+SDD

b. Dependent Variable: ROE 
Todorović V. et al.:Impact of the single euro payment area on performance of banking..

Table 15. Coefficients for regression - group C (ROE as dependent variable)

\begin{tabular}{|c|c|c|c|c|c|c|c|c|}
\hline & \multirow{2}{*}{ Model } & \multicolumn{2}{|c|}{$\begin{array}{l}\text { Unstandardized } \\
\text { Coefficients }\end{array}$} & \multirow{2}{*}{$\begin{array}{c}\begin{array}{c}\text { Standardized } \\
\text { Coefficients }\end{array} \\
\text { Beta }\end{array}$} & \multirow{2}{*}{$\mathrm{t}$} & \multirow{2}{*}{ Sig. } & \multicolumn{2}{|c|}{ Collinearity Statistics } \\
\hline & & B & $\begin{array}{l}\text { Std. } \\
\text { Error }\end{array}$ & & & & Tolerance & VIF \\
\hline \multirow{3}{*}{1} & (Constant) & 9,852 & 1,455 & & 6,770 & , 000 & & \\
\hline & $\mathrm{SCT}+\mathrm{SDD}$ &,- 671 & ,428 &,- 315 & $-1,568$ &, 125 & ,438 & 2,281 \\
\hline & EMV &,- 056 &, 038 &,- 299 & $-1,491$ & , 144 &, 438 & 2,281 \\
\hline
\end{tabular}

a. Dependent Variable: $R O E$

\section{Discussion and conclusion}

The idea of forming a single payment area in the Euro-region is relatively new and today refers to 33 countries of Europe. Lack of integration of national payment system represented constraint to further development of the European economy, and previous attempts (establishment of TARGET system) failed to provide the desired degree of integration.

Unlike the national payment system, SEPA project is organized in three levels, where the infrastructure system clearly separates the specific schemes and products. In addition to structure of the system, an important element of the entire project is a framework of regulation behavior of the participants. In this regard, there have been relevant regulations and directives of the European Commission, which have largely contributed to harmonization of payment systems and the creation of conditions for the easy application of SEPA rules. SEPA system refers to three types of instruments, and to SEPA credit transfers, SEPA direct debit and the SEPA payment cards. For each of these instruments there have been developed specific rules that ensure uniformity in the use across entire area of Euro area. Special attention was paid to the SEPA direct debit, where is possible to distinguish between basic and Business (B2B) schemes. In addition, in the context of the effectiveness of implementation SEPA rules, rules relating to direct debits are far behind in this process.

In the literature, there are specified four possible scenarios of implementation SEPA rules, which can be regarded as a phases of the implementation process. Each scenario assumes that users have some benefits from the system, but they are greatest in ideal SEPA system. Based on current development SEPA system it can be concluded that the entire process of implementation is in the second phase. Although the system is actually located at the transition from the second to the third stage of the implementation process, the participants still can feel all the benefits of the system. As the two main stakeholders can be distinguished SEPA service 
Todorović V. et al.:Impact of the single euro payment area on performance of banking..

providers and their customers. Measuring the effects of the of implementation SEPA rules for individual participants is complicated by the fact that it can appear as providers and users of SEPA services.

The paper explored the effects of the implementation process SEPA rules on banks as participants in this process. Hypotheses that are set in accordance with previous research and theoretical knowledge were tested in three groups of countries. The study included a test of normality, correlation analysis and two multiple regression models (ROA and ROE as dependent variables) that have been tested in all three groups of countries.

Multiple regression analysis involves two models. The first model is used to analyze the effects of SEPA-compatible instruments (SCT+SDD and EMV) on ROA and has been tested in all three groups of countries. Results indicate that within groups $A$ and $C$, a statistically significant impact on the amount of ROA has only EMV, while this is not the case with the SCT+SDD. On the other hand, in the B group of countries, both independent variables have a statistically significant influence on the ROA. The regression coefficients indicate that the effect was negative and therefore the hypothesis $H_{1}$ is confirmed only when it comes to the second group of countries, while $\mathrm{H}_{2}$ was confirmed in all three groups.

Another model of multiple regressions analyses identifies ROE as dependent variable. Based on the results it can be concluded that the effects of SCT+SDD and EMV on ROE is statistically significant when are concerned groups $A$ and $B$, which is not the case when it comes to group $C$. The regression coefficients confirm hypotheses $\mathrm{H}_{3}$ and $\mathrm{H}_{4}$ in groups $A$ and $B$, but in group $\mathrm{C}$ both hypotheses are rejected.

Based on the above, it can be concluded that with the increase in share of SEPA compliant credit transfers and direct debits in total transactions of credit transfers and direct debits - SCT+SDD, the impact of this variable becomes statistically significant factor in the amount of ROA. On the other hand, the independent variable (SCT+SDD and EMV) affect the amount of ROE in less developed banking sectors in the EMU (groups A and B), which is not the case with group $C$. With the values of the regression coefficients, it can be concluded that the development and implementation of the SEPA rules leads to a deterioration in the performance of banking sector in the period 20022012th, confirming the starting hypothesis.

Results of the research are in cohesion with the views that in the short term benefits of SEPA project is not enough in compare with the costs. Respectively, the effects that are highly beneficial in the long term may be quite unfavorable in the short term. Therefore, so far the effects on performance banking sectors in EMU negative. However, it can be expected 
Todorović V. et al.:Impact of the single euro payment area on performance of banking..

that in the future surpass the cost benefits which will result in improving the performance of the banking sector.

However, it should be noted that changes in the performance of the banking sector should not be seen only as a result of replacing national schemes with SEPA compliant schemes. Implementation of SEPA rules leads to strengthening of competition between banks and payment institutions, which also affects the performance of banks. In this context, further research is necessary to improve the shown model and adapt it to the needs for research the effects of competition between banks and payment institutions on the performance of the banking sector.

\section{References}

Beccalli, E., (2007). IT and European Bank Performance, Palgrave Macmillan, London Bolt, W., Humphrey, D., (2007). Payment Network Scale Economies, SEPA, and Cash Replacement, Review of Network Economics, Concept Economics, 6 (4), 453473.

Bott, J., (2009). The Single Euro Payment Area: New Alliances Required to Tip the Market. Centre for European Policy Studies. ECRI Research Report No. 10, July 2009

Chaplin, J., (2008). Eight predictions for SEPA's Impact on payments cards, in Skinner C. (Ed.), The Future of Finance after SEPA (pp.99-107), John Wiley \& Sons.

Danese, D., (2008). Banking after SEPA: 2010 and beyond, In Skinner C. (Ed.), The Future of Finance after SEPA (pp.159-165). John Wiley \& Sons

De Ploey, W., Denecker, O., \& Kehrman, T., (2005), European Payment Profit Pool Analysis: Casting Light in Murky Waters, McKinsey \& Company

De Schrevel G., (2008). Was SEPA worth the effort after all?. in Skinner C. (Ed.), The Future of Finance after SEPA (pp. 71-77). John Wiley \& Sons

EBA, (2012). A guide to the SEPA migration end-date regulation, Euro Banking Association, Paris

ECB, (2009). Euro system's SEPA expectations, European Central Bank, Frankfurt

ECB, (2013). SEPA migration report. European Central Bank, Frankfurt

EC, (2001). Regulation 2650/2001. Official Journal of the European Communities. European Commission. Brussels

EC, (2007). Directive 2007/64/EC, Official Journal of the European Communities, European Commission, Brussels

EC, (2009). Regulation 924/2009, Official Journal of the European Communities, European Commission Brussels

EC, (2012). Regulation 260/2012, Official Journal of the European Communities, European Commission. Brussels

EPC, (2009). SEPA cards framework, European Payment Council, Brussels

EPC, (2012a). SEPA business to business direct debit - scheme rulebook, European Payment Council, Brussels

EPC, (2012b). SEPA core direct debit - scheme rulebook, European Payment Council, Brussels 
Todorović V. et al.:Impact of the single euro payment area on performance of banking..

European central bank (2013) www.ecb.europa.eu/paym/sepa/about/indicators/html/index.en.html (date of access: 24.10 .2013 .)

Kasavica P., Jović, Z. (2015) Impact of asset quality on bank profitability - Case study, Industrija, 43(4). 105-128

Kemppainen, K., (2008). Integrating European retail payment systems: some economics of SEPA, Bank of Finland, Research Discussion Papers. (22).

Kokkola, T. (Ed), (2010). The payment system - payments, securities and derivatives, and the role of Euro system, European Central Bank, Frankfurt

Leinonen, H., (2008). After 2010: Will the Customer become King?, In Skinner C. (Ed.), The Future of Finance after SEPA (pp. 141-149). John Wiley \& Sons

Martikainen, E., Schmiedel, H., \& Takalo, T., (2013). Convergence in European retail payments, European Central Bank, Occasional paper series, No 147 June 2013

O'Brien M. R., (2007). A Caution Regarding Rules of Thumb for Variance Inflation Factors, Quality \& Quantity, (41), 673-690

Ryan, J., (2008). SEPA: an introduction for corporates, in Skinner C. (Ed.), The Future of Finance after SEPA (pp.167-173). John Wiley \& Sons

Schmiedel, H., (2007). The Economic impact of the Single Euro Payments Area, European Central Bank, Occasional paper series. No 71 August 2007

Skinner, C., (2008). An Introduction to SEPA. in Skinner C. (Ed.), The Future of Finance after SEPA (pp.1-48), John Wiley \& Sons

Šoškić, D. (2015) EU banking union: Lessons for non-eurozone Transition countries, Industrija, 43(2), 165-181

Tabasso, G., \& Buschman, T., (2008). SEPA: the Corporative Perspective. In Skinner C. (Ed.), The Future of Finance after SEPA (pp.173-185). John Wiley \& Sons

Vuksanović, E., Todorović, V., \& Stefanović, R., (2011). SEPA project for the improvement of the European economy, Megatrend review, 8(2), 55-68

Wandhöfer, R., (2008). The Payment Service Directive - a critical view. In Skinner C. (Ed.), The Future of Finance after SEPA (pp. 115-119). John Wiley \& Sons 